\title{
Impact of vitamin A supplementation in anaemia during pregnancy: a randomized double blind controlled clinical trial
}

\author{
Shakun Singh, Rachana Chaudhary, Vandana Dhama, Anu Singh*, Urmila Karya
}

Department of Obstetrics and Gynaecology, L.L.R.M. Medical College, Meerut, Uttar Pradesh, India

Received: 19 March 2018

Accepted: 21 April 2018

*Correspondence:

Dr. Anu Singh,

E-mail: dranusingh29@gmail.com

Copyright: (C) the author(s), publisher and licensee Medip Academy. This is an open-access article distributed under the terms of the Creative Commons Attribution Non-Commercial License, which permits unrestricted non-commercial use, distribution, and reproduction in any medium, provided the original work is properly cited.

\begin{abstract}
Background: To study the impact of Vitamin A supplementation in anaemia during Pregnancy and thus improving maternal and fetal outcome a Randomized double blind controlled clinical trial was conducted in Department of Obstetrics and Gynaecology, L.L.R.M. Medical college Meerut involving 250 pregnant women in late pregnancy 1828 weeks with haemoglobin levels $<11 \mathrm{~g} \%(7-11 \mathrm{~g} \%)$..

Methods: The study subjects were divided into two groups: Group A ( $n=125)$ : Received daily supplement containing Iron $(60 \mathrm{mg}$ elemental iron) + Folate $(500 \mathrm{mcg})+$ Vitamin A 20,000 IU weekly for a minimum of 12 weeks. Group B $(n=125)$ : Received daily supplement containing iron $(60 \mathrm{mg}$ elemental iron $)+$ Folate $(500 \mathrm{mcg})$ for a minimum of 12 weeks.

Results: Maximum patients were uneducated belonging to low socioeconomic status. The mean haemoglobin values in Group A and Group B increased from $9.674 \pm 1.05$ and $9.53 \pm 1.04$ to $12.2 \pm 0.89$ and $10.82 \pm 1.06$ respectively after supplementation. Similarily Serum Ferritin levels increased from 15.96 \pm 2.94 and $15.70 \pm 2.83$ to $78.40 \pm 17.82$ and 58.64 \pm 11.93 . Mean corpuscular volume, packed cell volume and red blood cell counts also increased significantly. Maximum haemoglobin levels were achieved with both vitamin A and iron supplementation. The proportion of women who became non anaemic was $97.17 \%$ in Group A vs $68.69 \%$ in Group B.

Conclusions: Vitamin A supplementation improves anaemia and also dramatically improves iron stores in anaemic pregnant women.
\end{abstract}

Keywords: Anaemia, Pregnancy, Vitamin A

\section{INTRODUCTION}

Anaemia is the most common haematological abnormality diagnosed during pregnancy. In India $16 \%$ of maternal deaths are attributed to anaemia.

The association between anaemia and adverse pregnancy outcome, higher incidence of pre-term and low birth weight deliveries has been demonstrated, however high prevalence of anaemia in pregnancy persists in India despite the availability of effective, low cost interventions for prevention and treatment. ${ }^{1}$ Vitamin A is a fat soluble vitamin found in liver kidney, eggs and dairy products.
Vitamin A appears to be involved in pathogenesis of anaemia through diverse biological mechanisms such as enhancement of growth and differentiation of erythrocyte progenitor cells, potentiation of immunity to infection, reduction of anaemia of infection and mobilization of iron stores from tissues. ${ }^{2}$

Chawla and Puri have demonstrated significant positive relationship between concentrations of vitamin $A$ in serum and biochemical indicators of iron status. ${ }^{3}$ Vitamin A treatment also increases circulating haemoglobin during pregnancy, probably by increasing Insulin like growth factors-1 which has function in Erythropoiesis. ${ }^{4}$ 
In pregnancy extra Vitamin A is required for growth and tissue maintenance in fetus, fetal reserves and maternal metabolism with basal requirement of $370 \mathrm{mcg} /$ day maximum up to $3000 \mathrm{mcg} /$ day and RDA of 770 mcg/day. ${ }^{5-7}$ However in first 60 days post conception Vitamin A is teratogenic. So WHO expert group consultation concluded that daily dose of up to 10,000 IU (3000 mcg retinol) or 25000 IU weekly after 60 days are probably safe..$^{8,9}$ Mills et al found no association between periconceptional Vitamin A exposure at doses of $>8000$ IU or $>10,000$ IU per day and malformations in cranial neural crest defects or neural tube defects. ${ }^{10}$

Therefore vitamin a supplementation in late pregnancy can improve maternal haematological parameters and thus can improve maternal and newborn outcome.

\section{METHODS}

This study was carried out in Department of Obstetrics And Gynaecology, L.L.R.M. Medical College \& S.V.B.P. Hospital Meerut, Uttar Pradesh during one year period from 2016-2017. The Institutional Ethical Review Board approved the study, and we obtained a written informed consent from all participants before enrollment.

250 pregnant women (Age: 21-35 yrs) in late pregnancy (18-28 weeks) who had haemoglobin levels $<11$ gm\% (7$11 \mathrm{gm} \%$ ), primigravida /second gravida, resident within the Study Area belonging to Low/Middle Socioeconomic status and Willing to have follow up every week were enrolled in this study. we excluded the women with HIV infection, tuberculosis, recurrent pregnancy loss / earlier preterm births, diabetes / hypertension / acute-infections / heart diseases / pre-eclampsia or any other metabolic disorders.

Subjects were randomized by a statistician, not otherwise involved in the study by lottery method in 1:1 ratio in two groups. A single intern was responsible for packaging of both drugs in packets labeling them as A and B. Only the intern knew what the medication was in packet A and B. So neither the clinician nor the women knew the type of preparation.

Group A: Received daily supplement containing Iron (60 mg elemental iron) + Folate $(500 \mathrm{mcg})$ (available as free hospital supply) + Vitamin A 20,000 IU (health vitamin vit. A dry, west coast pharmaceutical) weekly for a minimum of 12 weeks. This group included 125 patients in the beginning of the study but only 106 patients were available till end.

Group B ( $\mathrm{n}=125)$ : Received daily supplement containing iron $(60 \mathrm{mg}$ elemental iron) + Folate $(500 \mathrm{mcg})$ for a minimum period of 12 weeks. This group also included 125 patients out of which 115 patients completed the study.
Both the groups were given deworming therapy tablet Albendazole $400 \mathrm{mg}$ orally single dose._Primary outcome was Improvement in haemoglobin levels in pregnant females. Improvement in Haematological parameters. Improvement in Iron stores (in terms of serum ferritin). Prevention of low birth weight. Secondary outcome included, reduction in maternal clinical infections, improvement in sense of well being, prevention of pre term births and No new emergence of Congenital Anomalies. Sample size was calculated as $4 \mathrm{PQ} / \mathrm{D}^{2}$ taking $\mathrm{P}$ as $80 \%$ (prevalence of anaemia in pregnant females in india), Q is $100-\mathrm{P}, \mathrm{D}$ is allowable error $5 \%$ so a sample size of 256 was needed.

\section{Statistical analysis}

All data were analyzed using SPSS software Chicago, IL, USA, version 21. Data showed normal distribution, so they were presented as Mean \pm Standard deviation. Comparison between categorical variables in both groups was done by Chi- square test and continuous variables were compared using Student t-test. We considered $\mathrm{p}<0.05$ as a significant value.

\section{RESULTS}

500 women were assessed for eligibility and 250 were excluded, remaining 250 were randomized in two groups of 125 each, in the end 106 women in group A and 115 women in group B completed the study due to loss to follow up, no taking supplements properly, few refused to provide a second sample and a few did not turn up (Figure 1).

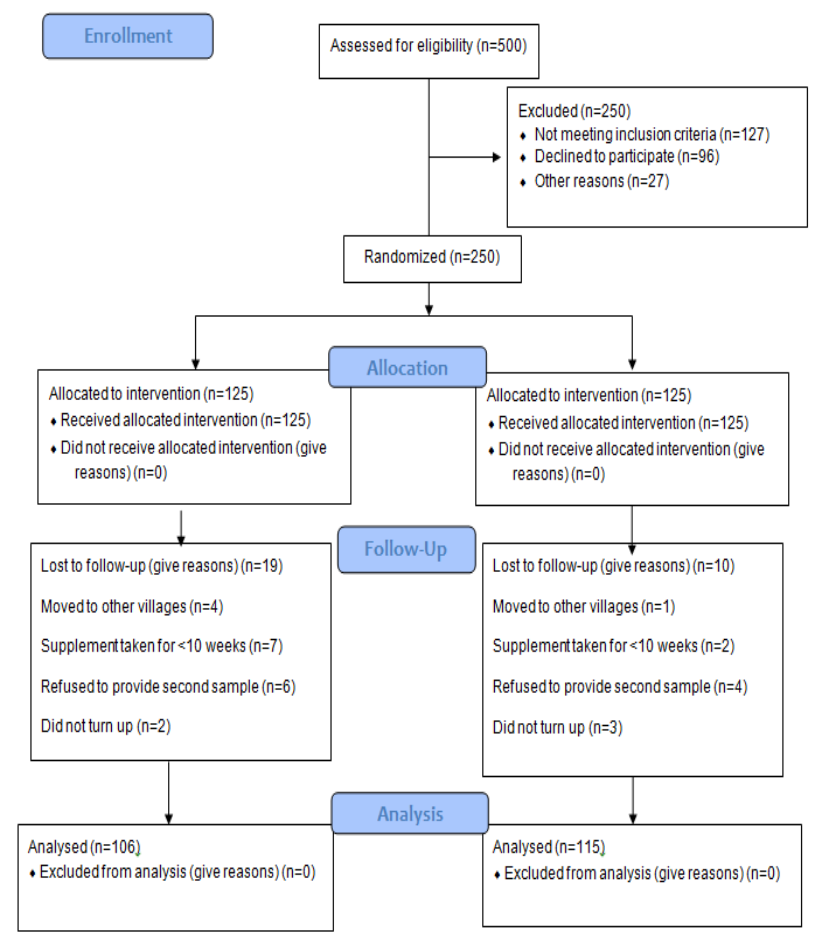

Figure 1: Flow diagram of study participants. 
Majority of women in both groups belonged to low socioeconomic status $(65.09 \%$ vs $88.69 \%)$ and mostly illiterate $(64.15 \%$ vs $87.82 \%)$.

The mean ages of subjects are comparable 24.44 \pm 3.0396 yrs for Vitamin A supplemented group and 24.76 \pm 2.718 yrs for Only IFA supplemented group. The mean period of gestation was also comparable between two groups $22.55 \pm 2.935$ weeks for Group A and 22.66 \pm 2.62 weeks for Group B.

Table 1: Distribution of demographic variables.

\begin{tabular}{|lll|}
\hline $\begin{array}{l}\text { Demographic } \\
\text { variables }\end{array}$ & Group A $(\mathbf{n = 1 0 6 )}$ & $\begin{array}{l}\text { Group B } \\
(\mathrm{n}=115)\end{array}$ \\
\hline Age & $24.44 \pm 3.03$ & $24.76 \pm 2.71$ \\
\hline $\begin{array}{l}\text { Period of } \\
\text { gestation }\end{array}$ & $22.55 \pm 2.935$ & $22.66 \pm 2.62$ \\
\hline Educated & $38(35.84 \%)$ & $14(12.17 \%)$ \\
\hline Uneducated & $68(64.15 \%)$ & $104(87.82 \%)$ \\
\hline High & 0 & 0 \\
\hline Middle & $37(34.90 \%)$ & $13(11.30 \%)$ \\
\hline Low & $69(65.09 \%)$ & $102(88.69 \%)$ \\
\hline Primigravida & $59(55.66 \%)$ & $54(46.95 \%)$ \\
\hline Multigravida & $47(44.33 \%)$ & $61(53.04 \%)$ \\
\hline
\end{tabular}

In group A maximum subjects were primi gravida while in Group B maximum were Second gravida however the obstetrical history in both groups was comparable, there was not a major difference in obstetrical history of both groups. Demographic variables were comparable in both groups (Table 1).

Mean haemoglobin values in group A and group B before supplementation were $9.674 \pm 1.057$ and $9.536 \pm 1.042$ respectively while after supplementation mean values were $12.2 \pm 0.892$ and $10.820 \pm 1.060$ respectively. The mean M.C.V. values before supplementation were 83.94 \pm 5.08 and $84.73 \pm 5.09$ in Group A and Group B respectively while after supplementation values increased to $86.81 \pm 3.07$ and $85.73 \pm 4.05$ respectively.

Mean P.C.V. in Group A and Group B Before supplementation were $26.95 \pm 2.51$ and $26.93 \pm 3.27$ which increased to $35.09 \pm 2.85$ and $31.16 \pm 3.27$. R.B.C. Counts also increased from $3.22 \pm 0.352$ in Group $A$ and $3.15 \pm 0.345$ in Group B to $4.03 \pm 0.31$ and $3.61 \pm 0.37$.
Table 2: Pre supplementation haematological parameters.

\begin{tabular}{|l|ll|l|}
\hline Parameters & $\begin{array}{l}\text { Group A } \\
(\mathbf{n}=106) \\
\text { Mean } \pm \text { S.D. }\end{array}$ & $\begin{array}{l}\text { Group B } \\
(\mathrm{n}=115) \\
\text { Mean } \pm \text { S.D. }\end{array}$ & $\begin{array}{l}\text { P } \\
\text { value }\end{array}$ \\
\hline $\mathrm{Hb}(\mathrm{gm} / \mathrm{dl})$ & $9.674 \pm 1.057$ & $9.536 \pm 1.042$ & 0.329 \\
\hline M.C.V.(fl) & $83.94 \pm 5.08$ & $84.73 \pm 5.09$ & 0.249 \\
\hline P.C.V.(\%) & $26.95 \pm 2.51$ & $26.93 \pm 3.27$ & 0.959 \\
\hline $\begin{array}{l}\text { R.B.C.counts } \\
\text { (million/cumm) }\end{array}$ & $3.22 \pm 0.352$ & $3.15 \pm 0.345$ & 0.287 \\
\hline $\begin{array}{l}\text { Serum } \\
\text { Ferritin(ng/ml) }\end{array}$ & $15.96 \pm 2.94$ & $15.70 \pm 2.83$ & 0.503 \\
\hline
\end{tabular}

Serum ferritin levels showed marked improvement from $15.96 \pm 2.94$ in Group A and $15.70 \pm 2.83$ in Group B to $78.40 \pm 17.82$ and $58.64 \pm 11.93$ in both groups respectively (Table 2 and 3).

Table 3: Post supplementation haematological parameters.

\begin{tabular}{|lll|l|}
\hline Parameters & $\begin{array}{l}\text { Group A } \\
(\mathbf{n}=106) \\
\text { Mean } \pm \text { S.D. }\end{array}$ & $\begin{array}{l}\text { Group B } \\
(\mathbf{n}=115) \\
\text { Mean } \pm \text { S.D. }\end{array}$ & $\begin{array}{l}\text { P } \\
\text { value }\end{array}$ \\
\hline $\mathrm{Hb}(\mathrm{gm} / \mathrm{dl})$ & $12.2 \pm 0.892$ & $10.820 \pm 1.060$ & 0.0001 \\
\hline M.C.V.(fl) & $86.81 \pm 3.07$ & $85.73 \pm 4.05$ & 0.0275 \\
\hline P.C.V.(\%) & $35.09 \pm 2.85$ & $31.16 \pm 3.27$ & 0.0001 \\
\hline $\begin{array}{l}\text { R.B.C.Counts } \\
\text { (million/cu } \\
\text { mm) }\end{array}$ & $4.03 \pm 0.311$ & $3.61 \pm 0.377$ & 0.0001 \\
\hline $\begin{array}{l}\text { Serum } \\
\text { Ferritin(ng/ml) }\end{array}$ & $78.40 \pm 17.82$ & $58.64 \pm 11.93$ & 0.0001 \\
\hline
\end{tabular}

Before supplementation $61.32 \%$ subjects had mild anaemia in Group A which reduced to $0 \%$ and $38.67 \%$ subjects had moderate anaemia which reduced to $7.31 \%$. Clinical oucome in terms of Birth Weight in both groups was also compared. Birth Weight was $2.94 \pm 0.45 \mathrm{~kg}$ in Group A and 2.81 $\pm 0.37 \mathrm{~kg}$ in Group B (p value<0.0195).

According to Table 4 C.R.P. values in both groups were also compared. Before supplementation C.R.P. Values in

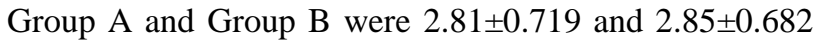
and after supplementation C.R.P. Values declined to $1.15 \pm 0.421$ and $2.053 \pm 0.556$ ( $\mathrm{p}$ value $<0.0001$ ). The incidence of pre-term births in Group A was $8.49 \%$ vs $4.78 \%$ in Group B.

Table 4: Comparison between CRP Value between Group A \& Group B.

\begin{tabular}{|lllll|l|}
\hline Parameter & $\begin{array}{l}\text { Group A } \\
\text { Before } \\
\text { treatment }\end{array}$ & After treatment & Before treatment & After treatment & P value \\
\hline CRP & $2.81 \pm 0.719$ & $1.15 \pm 0.421$ & $2.85 \pm 0.682$ & $2.053 \pm 0.556$ & $\begin{array}{l}\text { T1(A) Vs T1 (B) } \\
<0.6717 \text { T2(A) Vs T2 } \\
\text { (B) < }<0.0001\end{array}$ \\
\hline
\end{tabular}




\section{DISCUSSION}

Nutritional anaemia is a very serious problem worldwide and pregnant women and those living in developing countries are at particular risk. Hodges et al studied moderate anaemia which did not respond to medicinal iron but did to vitamin A. ${ }^{11}$

In the present study most cases were of low socioeconomic status, uneducated and younger than 30 years of age, maximum women were in their first or second pregnancy. Similar to the study Suharno et al also observed that mean age of pregnant women was 25.9 and were of low socioeconomic status. ${ }^{12}$ It was found that values of haemoglobin, M.C.V., P.C.V., R.B.C. Counts were significantly higher in iron and vitamin $A$ supplemented Group ( $\mathrm{p}<0.0001)$. Chawla and Pandey et al also confirmed that supplementation of iron alone or along with Vitamin A in second half of pregnancy results in improvement of haemoglobin, PCV and RBC count but the combination is more beneficial than iron alone. ${ }^{3,13}$

Serum Ferritin levels also increased significantly $(p<0.0001)$ in our study similar were findings of Sun et al that vitamin A and iron supplementation was more beneficial to improve iron status in pregnant women than iron alone. ${ }^{14}$ In present study we found a positive correlation between Birth Weight and Vitamin A supplementation. However Panth, Shatrughna et al found that vitamin A supplementation did not affect birth weight. ${ }^{15}$ Mean C.R.P. values also declined after Vitamin A supplementation signifies the reduction in clinical infections..

\section{CONCLUSION}

This study indicates that vitamin A supplementation reduces anaemia in pregnant women, regular and adequate intake of vitamin A by women during their reproductive years can reduce the risk of pregnancy related complications, improve birth weight and reduce the incidence of pre term births. Further work is needed to open the way to new prevention strategies that can be widely implemented in near future.

Funding: No funding sources

Conflict of interest: None declared

Ethical approval: The study was approved by the Institutional Ethics Committee, L.L.R.M. Medical college, Meerut, Uttar Pradesh, India

\section{REFERENCES}

1. Lokare PO, Karanjekar VD, Gattani PL, Kulkarni AP. A study of prevalence of anemia and sociodemographic factors associated with anemia among pregnant women in Aurangabad city, India. Ann Nigerian Med. 2002; 6(1):30-4.

2. van den Broek N, Dou L, Othman M, Neilson JP, Gates S, Gülmezoglu AM. Vitamin a supplementation during pregnancy for maternal and newborn outcome. Cochrane Database Syst Rev. 2010;(11):CD008666.

3. Chawla PK, Puri R. Impact of nutritional supplements on hematological profile of pregnant women. Indian Pediatr. 1995;32(8):876-80.

4. Arguello MA, Schulze KJ, Wu LS, Dreyfuss ML, Khatry SK, Christian P, et al. Circulating IGF-1 may mediate improvements in haemoglobin associated with vitamin A status during pregnancy in rural Nepalese women. Asia Pac J Clin Nutr. 2015;24:128-37.

5. Recommended nutrient intakes for pregnant and lactating adolescents (14-18 years); FNB 2001

6. Stipanuk MH, Caudill MA. Biochemical, Physiological \& Molecular Aspects of Human Nutrition. 3rd ed., Saunders; 2013.

7. World health report; WHO 1995. Available at http://www.who.int/whr/1995/en/

8. WHO 1998. Available http://www.who.int/whr/1998/en/

9. Rothman KJ, Moore LL, Singer MR. Vitamin A and birth defects. Lancet. 1996;347:321-2.

10. Mills JL, Simpson JL, Cunningham GC, Conley MR, Rhoads GG. Vitamin A and birth defects. Am J Obstet Gynecol. 1997; 177:31-6.

11. Hodges RE, Sauberlich HE, Canham JE, Wallace DL, Rucker RB, Mejia LA, et al. Hematopoietic studies in vitamin A deficiency. Am J Clin Nutr. 1978;31:876-85.

12. Suharno D. The role of vitamin A in nutritional anaemia: A study in pregnant women in West Java, Indonesia; 1994.

13. Pandey P, Mukherjee K, Pande S, Perhar I. Role of vitamin A supplementation in anaemia during pregnancy. Indian Obstet Gynaecol. 2015;5:3.

14. Sun YY, Ma AG, Yang F, Zhang FZ, Luo YB, Jiang DC, et al. A combination of iron and retinol supplementation benefits iron status, IL-2 level and lymphocyte proliferation in anemic pregnant women. Asia Pac J Clin Nutr. 2010;19:513-9.

15. Panth M, Shatrugna V, Yasodhara P, Sivakumar B. Effect of vitamin A supplementation on haemoglobin and vitamin A levels during pregnancy. Br J Nutr. 1990;64:351-8.

Cite this article as: Singh $\mathrm{S}$, Chaudhary R, Dhama V, Singh A, Karya U. Impact of vitamin A supplementation in anaemia during pregnancy: a randomized double blind controlled clinical trial. Int J Reprod Contracept Obstet Gynecol 2018;7:2262-5. 